\title{
Laryngeal Papillary Carcinoma in a Developing Community
}

\author{
Wilson Onuigbo ${ }^{1 *}$ and Nnenna Mgbor $^{2}$ \\ ${ }^{1}$ Departments of Pathology and Ear, Nose \& Throat, Nigeria \\ ${ }^{2}$ The University of Nigeria Teaching Hospital, Nigeria
}

Submission: January 15, 2018; Published: January 29, 2018

*Corresponding author: Wilson Onuigbo, Departments of Pathology and Ear, Nose \& Throat, Nigeria, Email: wilson.onuigbo@gmail.com

\begin{abstract}
Literature search revealed the rarity of laryngeal papillary carcinoma. A case from Brazil was reported as papillary carcinoma in the headline but as "papillary squamous cell carcinoma" on histopathological study. In the present study, the papillary nature was demonstrated classically.

Keywords: Larynx; Cancer; Papillary; Developing community
\end{abstract}

\section{Introduction}

According to the literature, laryngeal papillary carcinoma is rare. In a Brazilian report, it was head lined as "laryngeal papillary carcinoma" [1]. A 42-year-old white female complained of dysphonia and pain in the right cervical area; this proved on histopathology to be "papillary squamous cell carcinoma." Therefore, the present case of the purely papillary carcinoma merits reporting from a developing community inhabited by the Igbo Ethnic Group in Nigeria [2].

\section{Case Report}

OL, a 26-year-old Igbo female, attended the ENT Clinic run by the junior author (NM). The complaint was hoarseness of 5 years duration. Multiple papilloma was queried and routine biopsy was carried out. The specimen sent to the senior author (WO) consisted of several small fragments. Microscopy revealed a papillary structure with layers of mitotically active cells which did not form cell nests. Accordingly, pure papillary carcinoma was diagnosed.

\section{Discussion}

A Birmingham (UK) group attested to the utility of the establishment of a histopathology data pool in facilitating epidemiological analysis [3]. It was such a pool that facilitated our previous publication on the inverted papilloma of the nose and paranasal sinuses [4]. In this context, what did we find on searching the Internet on papers generalizing on the types of laryngeal carcinomas? For example, mention was not made of the papillary type in the large Scottish series [5]. Usually, the series was specified to be epidermoid carcinoma [6]. Indeed, a Liverpool review stated that "Virtually all laryngeal cancers are squamous in type" [7]. Concerning occupational and environmental associations, vocal abuse has been identified [8]. In this context, our patient was not known for being a singer. Incidentally, the age range in the mentioned Scottish series was 30 to 85 years, with the average of 62 years [5]. Curiously, our patient was younger than their youngest.

\section{References}

1. Fonseca AS, Chone CT, Crespo AN, Altemani A (2006) Laryngeal papillary carcinoma with unexpected evolution: Case report. Sao Paulo Med J 124(3): 158-160.

2. Basden GT (1966) Niger Ibos. Lond: Cass.

3. Macartney JC, Rollaston TP, Codling BW (1980) Use of a histopathology data pool for epidemiological analysis. J Clin Pathol 33(4): 351-353.

4. Onuigbo WIB, Mgbor N (2003) Inverted papilloma of the nose and paranasal sinuses. J Coll Med 8: 33-35.

5. Robertson AG, Boyle P, Deuchars F, Robertson C (1987) Carcinoma of the larynx. J Surg Oncol 35: 217-222.

6. Sessions DG (1976) Surgical pathology of cancer of the larynx and hypopharynx. Laryngoscope 86(6): 814-839.

7. Ramdan MF, Morton RP, Stell PM, Pharoah POD (1982) Epidemiology of laryngeal cancer.Clin Otolaryngol 7: 417-428.

8. Cowles SR (1983) Cancer of the larynx: Occupational and environmental associations. South Med J 76(7): 894-898. 
(C) Commons Attribution 4.0 License BY DOI: $10.19080 /$ GJ0.2018.13.555856
Your next submission with Juniper Publishers will reach you the below assets

- Quality Editorial service

- Swift Peer Review

- Reprints availability

- E-prints Service

- Manuscript Podcast for convenient understanding

- Global attainment for your research

- Manuscript accessibility in different formats

( Pdf, E-pub, Full Text, Audio)

- Unceasing customer service

Track the below URL for one-step submission https://juniperpublishers.com/online-submission.php 